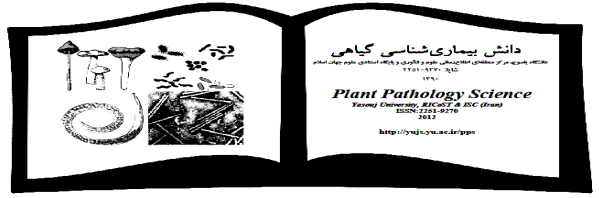

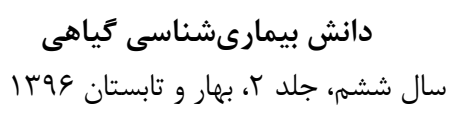

Plant Pathology Science

Vol. 6(2), 2017

\title{
Hyrcanian Boxwood Blight Disease
}

SAMANEH SAMAVAT ${ }^{\bowtie}$

Research institute of Forests and Rangelands, Agricultural Research Education and Extension Organization (AREEO), Tehran, Iran ( $\square$ : samavat.samaneh@ gmail.com)

Received: 10.01.2017

Accepted: 29.05.2017

Samavat S. 2017. Hyrcanian boxwood blight disease. Plant Pathology Science 6(2): 89-96.

Abstract: Hyrcanian boxwood which is one of the evergreen shrubs is native of northern forests of Iran. Blight disease caused by Calonectria pseudonaviculata is one of the most important diseases of this plant, which causes severe leaf loss and decline in susceptible cultivars. This disease has been reported from the forests of Gilan and Mazandaran provinces. The history and importance of the disease, geographical distribution, disease symptoms, pathogen characteristics, the disease cycle, and the methods for disease prevention as well as the mechanical and chemical control measures are described.

Key words: Blight, Boxwood, Cylindrocladium

$$
\begin{aligned}
& \text { بيمارى سوختگى شمشاد خزرى } \\
& \text { سمانه سماوات } \\
& \text { مؤسسه تحقيقات جنكَلها و مراتع كشور، سازمان تحقيقات، آموزش و ترويج كشاورزى، تهران، ايران. }
\end{aligned}
$$

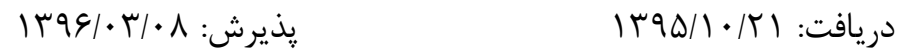

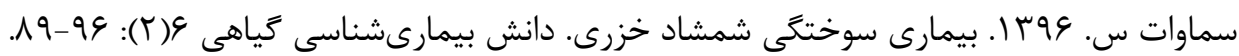

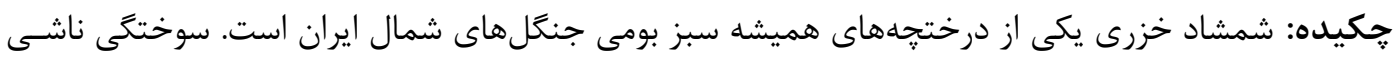

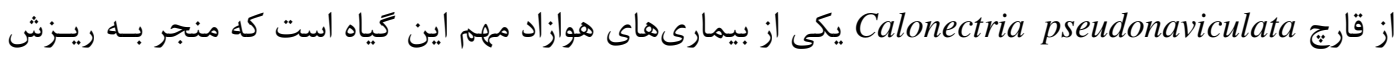

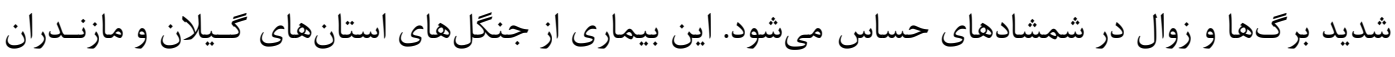

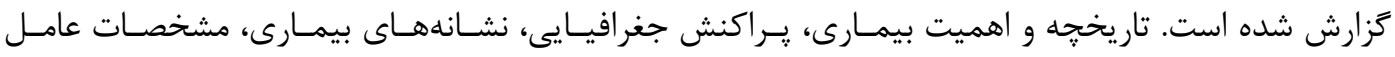

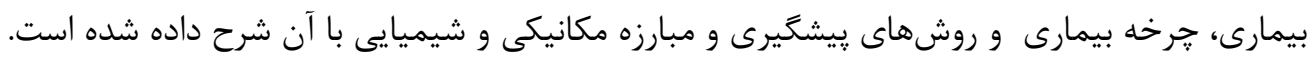

$$
\begin{aligned}
& \text { وازههاى كليدى: سوختكى، شمشاد جنگلى، Cylindrocladium } \\
& \text { مقدمه } \\
& \text { شمشاد خزرى (Buxus hyrcana Pojark.) از مهمترين گونهاى كياهى يهن برى و هميشه سبز بومى } \\
& \text { جنكلهاى هيركانى در شمال ايران است كه از دير زيستى نسبتاً بالايى (بالغ بر •اه سال) برخوردار } \\
& \text { مىباشد. در مناطق مختلف استانهاى كلستان، مازندران و گيلان نظير گرگان، بهشهر، زيارت، مازندران، } \\
& \text { نوشهر، نكا، دره تالار، نزديك يل سفيد، دره جالوس در ارتفاعات · · مترى از سطح دريا، اس كيلومترى قائم }
\end{aligned}
$$


شهر، كره زنخ دره هراز، نواحى مختلف درياى خزر، گيلان، اطراف رشت، لاهيجان، سياهكل، امام زاده هاشم، هشتير، املش، جنوب غربى رشت و امام زاده ابراهيم در ارتفاعات . .V-..9 مترى از سطح دريا مىرويد. اگرجه بيشترين ميزان رويش آن در جنكلهاى نوشهر و اسالم است ولى در تركمنستان و تالش نيز ديده مىشود. اين گياه داراى اسامى محلى متعددى است به گَنه اى كه در آستارا به شومشاد، در گيلان و طوالش به كيش، در سختسر و رودسر و تنكابن (شهسوار) به شومشاد و شيشار، در نور مازندران به شاروشر، در آمل و كجور به شهر و در تهران به شمشاد خزرى موسوم است (مظفريان عqجا). هر حند در منابع به عنوان يك نزاد جغرافيايى از گَونه شمشاد ارويايى (Buxus sempervirens L) معرفى مىشود، اما به دليل اختلافات كَاهشناسى و نيز خاستخاه جغرافيايى، از گونه مذكور متفاوت بوده و به عنوان يك آرايه كَاهى مجزا در پايكاه بين المللى نامهاى كياهان معرفى شده است (ثابتى خاصى برخوردار است و در فهرست گونههاى گياهى در خطر انقراض اتحاديه بينالمللى حفظ طبيعت قرار دارد (IUCN) عرصه هاى جنكلى شمال كشور را به خود اختصاص داده اند، اما متأسفانه در طى سالهاى اخير عوامل متعددى از جمله بيمارى قارجى سوختگى، اين گَونه بومى و با ارزش را مورد تهديد قرار داده است.

\section{1- تاريخجه، : يراكنش جغرافيايى و اهميت بيمارى}

اين بيمارى نخستين بار در سال 199 ميلادى در بريتانيا به وقوع ييوست و پس از آن در سراسر ارويا

به دليل انتقال مواد گياهى آلوده، انتشار يافت (Henricot \& Culham 2002). از آنجايى كه كياه شمشاد به عنوان يك گياه زينتى در دنيا مورد توجه است، انتشار اين بيمارى تنها به ارويا محدود نكرديد. در سال 1991 ميلادى بيمارى سوختخى شمشاد در نيوزلند مشاهده شد (Crous et al. 2002)، بيمارى نخستين بار در آمريكاى شمالى نيز در سال I| • ميلادى كزارش شده است. اين بيمارى تاكنون از آلمان، ايتاليا، اسيانيا، كرواسى، نروز، اتريش، جمهورى جک، دانمارك، جرجيا، بلزيك، ايرلند، هلند، فرانسه، تركيه، ايالت متحده آمريكا و كانادا كزارش شده است و از سال ع +. [ ميلادى بيمارى در فهرست بيمارىهاى گياهى تحت

مراقبت سازمان حفظ نباتات ارويا (EPPO) قرار كرفته است ( Gehesquiere et al. 2013$).$ 
بيمارى نخستين بار در ايران از تنكابن در استان مازندران و پس از آن از جنكلهاى استان كيلان كزارش شده است (Mirabolfathy et al. 2013). سيس انتشار آن تا منطقه بندرگز استان كلستان گزارش شد (خزائلى و همكاران ه9r()، كه اين امر نشان دهنده گسترش سريع بيمارى در مدت سه سال تا شرق جنكلهاى هيركانى است. هم اكنون ميزان خشكيدگى ناشى از اين بيمارى به بيش از • ع هزار هكتار از رويشگاههاى شمشاد خزرى رسيده است (Fakhredin \& Mirabolfathy 2014).

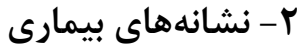

اولين نشانههاى بيمارى اغلب در اواخر بهار و يا اوايل تابستان روى برىها و ساقههاى شمشاد ظاهر

مىشود. از جمله اين نشانها مىتوان به ظهور لكههاى قهوهاى تيره با هاله زردرنگ روى بركها(شكل ())، خزان و ريزش شديد بركها از يائين درخت به بالا، خطوط سياهرنگ منقطع روى ساقهها، خشكيدگى سرشاخهها و از بين رفتن سريع درختجههاى شمشاد جنگلى اشاره كرد (Henricot et al. 2008)، كه به وضوح در بخشهاى آلوده جنكل هاى هير كانى قابل مشاهده مىباشند.

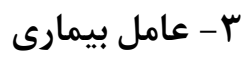

قalonectria pseudonaviculata (Crous, J.Z. Groenew. \& C.F. Hill) L. Lombard, M.J. قارج

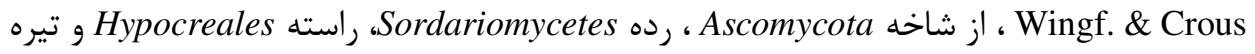

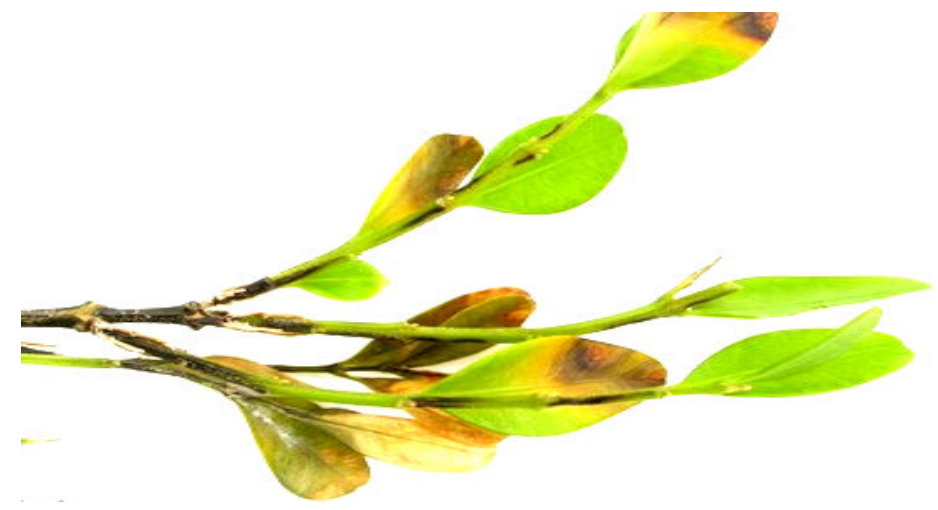

شكل ا- نشانههاى بيمارى سوختخى شمشاد به صورت لكههاى قهوه اى تيره با هاله زردرنت روى بركهـا و

$$
\text { خطوط سياهرنگ منقطع روى ساقه. }
$$

Figure 1. Symptoms of the boxwood blight as dark brown spots with yellow halo on leaves and distinct black streaks on stem. 
Nectriaceae

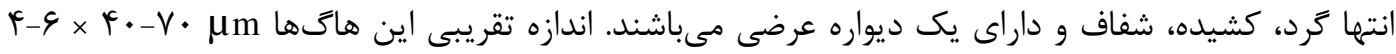
است. كنيديومبرها با پايهاى نسبتاً بلند و شاخههاى زاياى فرجه مانند هستند. همين طور در برخى قسمتهاى انتهايى داراى قسمتهاى برآمده به نام وزيكل هستند كه بيضى شكل بوده و داراى يستانك مىباشند (Henricot \& Culham 2002). اين قارج تنها روى انواع شمشاد و ارقام آنها بيمارىزا است. در اين ميان، گَونهاى شمشاد ارويايى و جنكلى بيشترين حساسيت به بيمارى دارند (Henricot \& Culham 2002). طبق ثروهش صورت گرفته.Buxus sinica var. insularis (Nakai.) M.Cheng مقاومت نسبى به بيمارى دارد (LaMondia 2015).

\section{F}

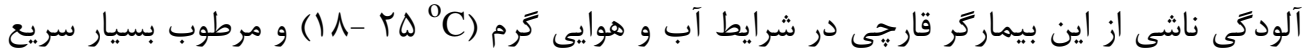

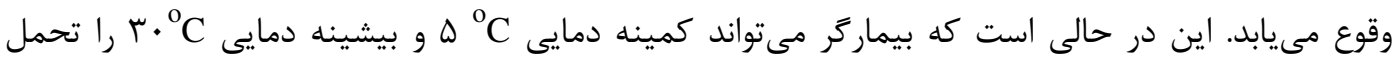
نمايد. هاكهاى اين قارج از خاصيت جسبندگى برخوردار هستند، بنابراين به نظر بعيد مىرسد تا آلودگى اوليه توسط هاگها كه توسط باد منتقل و منتشر مى شوند، صورت كيرد. هاگهايى كه توسط قطرات آب يراكنده مىشوند و يا هاتهايى كه توسط ناقلينى از حشرات، يرندكان و يا قطعات كياهى منتقل مى شوند، به احتمال بسيار زياد منبع آلودَى اوليه اين بيمارى هستند. جوانه زنى هاگها معمولاً سه ساعت پس از وقوع آلودگى رخ مى دهد. دماى بهينه براى جوانه زدن هاگهاى اين قارج Co م است. نفوذ قارج به بافت شمشاد، ينج ساعت يس از آلودگى صورت مى گيرد. در حقيقت، نفوذ از محل روزنههاى هوايى موجود در سطح تحتانى برگها و يا مستقيماً از محل كوتيكول موجود در سطح فوقانى برى رخ مى دهد. اين قارج براى نفوذ و يا تغذيه ساختار خاصى تشكيل نمى دهد. بيماركر مىتواند به صورت بين سلولى در بافتهاى درونى برگ رشد نمايد. ظهور مجدد قارج دو تا سه روز يس از آلودگى از محل روزنههاى هوايى صورت

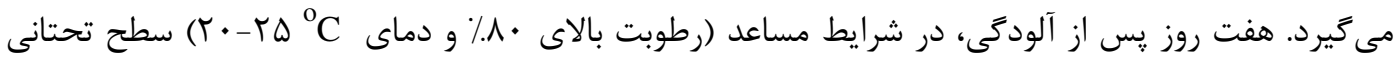
برى با لايهاى از كنيديومبرها و كنيديومهاى قارج، يوشيده مىشود. از آنجايى كه عامل اين بيمارى هوازاد است به همين خاطر در طى فصل مى تواند تعداد زيادى جرخه ثانويه به كمك هاگهاى خود تشكيل دهد 
كه معمولاً هر جرخه ثانويه در طى حدود يك هفته تكميل مىشود و در طى آن به سرعت مىتواند باعث ايجاد بيمارى شود. بركها سرانجام خشك مىشوند، احتمالاً اين امر به دليل تنش عمومى ناشى از اشغال فضاهاى بين سلولى توسط بيمارگر و عدم تنظيم يذيرى روزنهاى هوايى است. اين قارج مىتواند ساختارهاى استراحتى موسوم به ريزسختينه تشكيل دهد كه آن را قادر مى سازد تا در غياب ميزبان حساس خود در خاى بقا و دوام يابد. اين قارج مى تواند به صورت ريسه و ريزسختينهها در بقاياى بركهاى آلوده شمشاد تا حداقل ينج سال دوام آورد (Henricot et al. 2008).

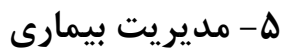

ه-ا- يِيشگيرى از بيمارى : رعايت اصول قرنطينه داخلى و خارجى با تشخيص و ممانعت از جابهجايى و انتقال قلمهها و نهال هاى آلوده شمشاد از مناطق آلوده به ساير مناطق، پايش بيمارى به طور دورهاى و دقيق، بخصوص در مناطقى كه آلودىى به بيمارى گَزارش شده، كاشت نهالهاى سالم و گواهى شده شمشاد، گَرفتن قلمه از يايههاى سالم و گَاهى شده، روشهاى ييشحَيرى از گسترش و شيوع بيمارى هستند.

ه-ץ- هرس درختجههاى بيمار و از بين بردن بقاياى گياهى آلوده : پايش بيمارى به طور دورهاى و دقيق، در مناطقى كه بيمارى به تازگى و در سطوح يائين در آنجا گزارش شده است انجام گيرد تا با مشاهده اولين نشانه هاى بيمارى، در كوتاهترين زمان ممكن اقدامهاى مؤثرى جهت مهار آن صورت گيرد. در صورت يائين بودن درصد آلودگى در يك درخت، هرس شاخههاى آلوده تا ه ه بالاتر از مرز بافت سالم با بافت آلوده در طى فصل تابستان كه قارج عامل بيمارى تا حدودى غيرفعال است، توصيه مى شود (دقت شود كه يس از هر بار هرس بايستى حاقو يا قيجى هرس توسط محلول هييوكلريت سديم (وايتكس) • (٪ ضدعفونى شود). همجنين پس از هرس بهتر است محل هرس توسط محلول آب آهك ضدعفونى گردد و يا توسط خسب پيوند باغبانى يانسمان شود تا احتمال وقوع ساير آلودىىها از محل زخم ناشى از هرس به حداقل برسد و شاخههاى آلوده و هرس شده نيز بايد سوزانده و يا تدفين شوند. به طور كلى هرس باعث بهبود جريان هوا و كاهش رطوبت مورد نياز براى بروز آلودگى توسط بيمارگر مىشود. با حذف بركهاى خزان شده پِى درختجه ها شمشاد به كمك سوزاندن و يا دفن بقايا مىتوان تا حدود زيادى منجر به حذف كانونهاى زمستانكذران بيماركر شد و به اين ترتيب ميزان آلودكى در سال بعد به ميزان قابل توجهى كاهش مى يابد. براى اين منظور 
مىتوان توسط دستخاههاى مكنده برگ، تمام بركهاى آلوده باقى مانده روى خاك را جمعآورى و سيس آنها را در يك محل تخليه و معدوم كرد. توجه شود كه نبايد از جنين بركهاى آلودهاى جهت تهيه كميوست استفاده گردد، زيرا همانطور كه قبلاً اشاره شده قارج عامل بيمارى قادر است تا ينج سال در بقاياى برگهاى آلوده دوام و بقا يابد. در صورت بروز آلودگى شديد در نهالهاى شمشاد واقع در يوشش كف جنكل كه تا ارتفاع حدود يك و نيم مترى از كف بالا آمدهاند و به صورت انبوه و تودهاى در منطقه رشد كردهاند، ريشه كنى و حذف تمام نهال هاى آلوده در منطقه توصيه مىشود. ه-r- مبارزه شيميايى: در مناطق خالى از سكنه كه ميزان شدت آلودگى ناشى از بيمارى بسيار بالا است، مىتوان با رعايت اصول ايمنى اقدام به مبارزه شيميايى نمود. براى اين منظور مىتوان از قارجكشهاى شيميايى نظير تبوكونازول با نام تجارتى Fungus Fighter@ و يا مخلوط تبوكونازول+ ترى فلوكسى استروبين با نام تجارتى Fungus Fighter Plus® به صورت محلولٍاشى استفاده كرد. اين سموم جذبى بوده و داراى اثرات حفاظتى و معالجهى هستند. در صورتىكه كاربرد اين سموم به عنوان معالج مد نظر باشد مىتوان به محض مشاهده اولين نشانهاى بيمارى اقدام به اولين محلولياشى كرد و پِ از آن هر • ا تا الب روز يكبار بر حسب شدت آلودگى اقدام به سمياشى كرد. البته در مورد شمشاد حداكثر تعداد محلولياشى در سال نبايد از شش مرتبه بيشتر گردد. اما اگر هدف از كاربرد اين سموم اثرات حفاظتى آن است تا پِيشخيرى از شيوع بيمارى در مناطق غير آلوده و يا مناطقى با حداقل آلودگى صورت گيرد، مى توان اولين محلولياشى را با ظهور اولين بركها در بهار انجام داد. زمان مناسب براى دومين محلولياشى، • إرز يس از اولين محلولياشى است. يֶ از آن هر دو هفته يكبار بايد محلولياشى در منطقه تكرار شود، در اين مورد نيز نبايد تعداد محلولياشىها در سال بيشتر از شش مرتبه باشد. از هركونه محلولياشى در زمان گردهافشانى و باز بودن كلها بايستى اكيداً اجتناب شود)(Brand 2006, Henricot \& Wedgwood 2013)

\section{نتيجه كَيرى و يِيشنهاد}

شمشاد خزرى از گياهان در معرض انقراض جنكل هاى شمال ايران محسوب مىشود. بيمارى سوختخى شمشاد در حل گسترش سريع از جنگلهاى استانهاى گيلان تا گلستان با سطح نسبتا بالاى آلودگى در برخى مناطق است. اجراى هر جه سريعتر روشهاى مديريت بيمارى شامل پيشخيرى از بيمارى با رعايت 
اصول قرنطينه و جلوَّيرى از جابهجايى و انتقال قلمهها و نهالهاى آلوده شمشاد و پِايش مداوم بيمارى،

هرس درختجههاى بيمار و از بين بردن بقاياى گياهى آلوده و در صورت آلودگى شديد و خطر خشكيدگى

وسيع اين درختجههاى هميشهسبز مبارزه شيميايى با قارجكشهاى تبوكونازول يا تبوكونازول+ ترى فلوكسى

استروبين با مشاركت سازمانهاى اجرايى، تحقيقاتى و ساكنين بومى ريشنهاد مىشود.

References

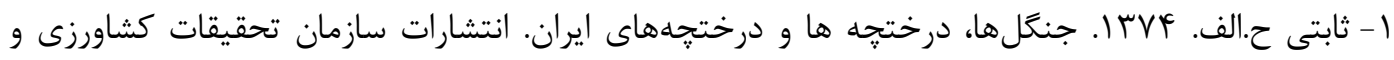
منابع طبيعى. · 11 ص.

ז- خزائلى ״.، رضائى س.، ميرابوالفتحى م.، زمانى زاده ح.ر. و كيادليرى ه. ه9؟1. يراكنش، شناسايى اختصاصى و تنوع بيماريزايى جدايههاى Calonectria pseudonaviculata عامل بيمارى سوختكى

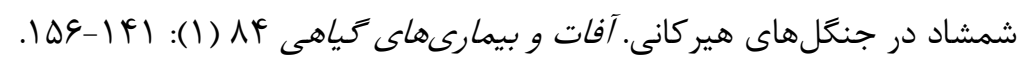

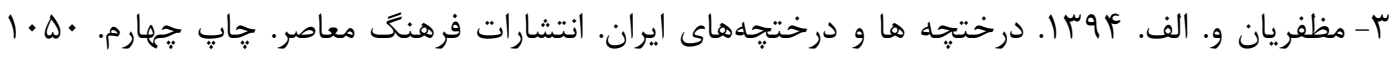

4- Brand T. 2006. In vitro action of fungicidal agents on conidial germination and mycelium growth of Cylindrocladium buxicola. Journal of Cultivated Plants 58:117-121.

5- Crous P.W., Groenewald J.Z. \& Hill C.F. 2002. Cylindrocladium pseudonaviculatum sp. nov. from New Zealand, and new Cylindrocladium records from Vietnam. Sydowia 54(1): 23-34.

6- Fakhredin F. \& Mirabolfathy M. 2014. Comparative effects of some fungicides to control boxwood blight. Proceeding of $21^{\text {st }}$ Iranian Plant Protection Congress, Iran. p.23.

7- Gehesquiere B., D’Haeyer S., Pham K.T.K., et al. 2013. qPCR assays for the detection of Cylindrocladium buxicola in plant, water and air samples. Plant Disease 97:1082-1090.

8- Harman G. \& Kubicek P. 1998. Trichoderma and Gliocladium: Enzymes, biological control and commercial applications. Taylor and Francis Ltd, London, England, 393 p. 
9- Henricot B. \& Culham A. 2002. Cylindrocladium buxicola, a new species affecting Buxus spp, and its phylogenetic status. Mycologia 94(6): 980-997.

10- Henricot B. \& Wedgwood E. 2013. Evaluation of foliar fungicide sprays for the control of boxwood blight caused by the fungus Cylindrocladium buxicola. Plant Health Progress. doi:10.1094/PHP-2013-1024-01-RS.

11- Henricot B., Gorton C., Denton G. \& Denton J. 2008. Studies on the control of Cylindrocladium buxicola using fungicides and host resistance. Plant Disease 92: 12731279.

12- Jalili A. \& Jamzad Z. 1999. Red data book of Iran: A preliminary survey of endemic, rare and endangered plant species in Iran. Research Institute of Forests and Rangelands, Tehran, Iran, $748 \mathrm{p}$.

13- LaMondia J.A. 2015. Management of Calonectria pseudonaviculata in boxwood with fungicides and less susceptible host species and varieties. Plant Disease 99(3): 363-369.

14- Lombard L., Crous P.W., Wingfield B.D. \& Wingfield M.J. 2010. Phylogeny and systematics of the genus Calonectria. Studies in Mycology 66: 31-69.

15- Mirabolfathy M., Ahangaran Y., Lombard L. \& Crous P.W. 2013. Leaf blight of Buxus sempervirens in northern forests of Iran caused by Calonectria pseudonaviculata. Plant Disease 97: 1121. 